\title{
The Frequency of Squamous Cell Carcinoma Among Patients with Long Standing Burn Scars
}

\author{
(1) Khalifa E. Sharquie', (1) Raed I. Jabbar ${ }^{2}$ \\ ${ }^{1}$ University of Baghdad, College of Medicine, Medical City Teaching Hospital, Department of Dermatology, Baghdad, Iraq \\ 2Fallujah Teaching Hospital, Al-Anbar Health Directorate, Department of Dermatology, Anbar, Iraq
}

\section{ABSTRACT}

Background: Burn scar is a common complication of severe deep burns and its management could be started by medical therapy and or followed by plastic surgery. Squamous cell carcinoma (SCC) could result as consequence of long standing burn scar.

Materials and Methods: This case series descriptive study where a total of 172 patients with burn scars were seen during the period from 2014-2021. These patients were screened for cases with post burn scar SCC and the different triggering factors were evaluated. Biopsies for histopathological assessment were done.

Results: A total of 172 patients with burn scar, their ages ranged from 1-50 years with a mean 25 year, 122 (71\%) males and 50 (29\%) females. All had history of burn and the age of the scar was ranged from $0.5-5$ years. Twelve (6.97\%) cases of SCC were seen among all patients with burn scars, their ages ranged from 25-50 years with long standing burn scar. The sites of these cancers were as follow: 6 (50\%) cases on lower limbs including the buttock, 5 (41.66\%) cases upper limbs and one (8.33\%) case on scalp. The associated triggering risk factors were male sex, deep burn scar with contracture, long duration, at the sites of flexures like elbows and knees. In addition to sites subjected to repeated trauma, ulcerations and infection.

Conclusion: The frequency of squamous cell among burn scars was 6.97\%. All patients with deep burn scar should be watched carefully for burn SCC especially scars in male with frequent infection, ulcerations, repeated trauma and contracture around the joints. Early medical therapy is strongly indicated but if this maneuver fails then excision and grafting might prevent this important complication.

Keywords: Burn scar, Ulcer, Squamous cell carcinoma

\section{Introduction}

A burn trauma is one of the most severe forms of injury to the skin and each year about 300,000 people die because of burns. Advancement in acute burn care has decreased mortality rate in the last few decades. After-burn injury, the prevalence of hypertrophic scarring is about $70 \%$ [1]. There are 2 varieties of scarring that follow burn trauma-keloid or hypertrophic scar.The period for the development of keloid usually ranged from months to years, while the hypertrophic scar usually appear 4-8 weeks post burn injury. keloid grow beyond the original defect while hypertrophic scar does not grow beyond the borders of the original defect $[2,3]$.

Squamous cell carcinoma (SCC) is a most common post burn scar cancer that originates from the malignant proliferation of the keratinocytes $[4,5]$. In the etiopathogenesis, different factors such as thermal factors, arsenic, solar factors, immunosuppression, chronic radiation, and viral factors are responsible [5,6].

Malignant transformation of post-burned scars is an unavoidable probability. About $2 \%$ of ulcers and deep burns that had been

Address for Correspondence: Khalifa E. Sharquie MD, University of Baghdad, College of Medicine, Medical City Teaching Hospital, Department of Dermatology, Baghdad, Iraq

Phone: +009647901468515 E-mail: ksharquie@ymail.com ORCID ID: orcid.org/0000-0002-0265-2040

Received: 30.06.2021 Accepted: 08.07.2021

${ }^{\circ}$ Copyright 2021 by the Society of Academy of Cosmetology and Dermatology / Journal of the Turkish Academy of Dermatology published by Galenos Publishing House. 
healed by secondary intention, unstable post-burned scars that frequently ulcerate due to repeated petty traumatic insult and those which never healed completely, will develop malignant transformation. This finding is commonly seen in the lower limbs, especially around joints such as the knees $[7,8,9]$. So the aim of the present work is to record all cases of SCC following burn scars and to evaluate the triggering risk factors involved in its pathogenesis.

\section{Materials and Methods}

This case series descriptive study where a total of 172 patients with burn scars were seen during the period from August 2014-January 2021. These patients were screened for cases with post burn scar SCC and the different etiological factors were evaluated. Biopsies for histopathological assessment using hematoxylin and eosin were done for every patient with chronic burn scar ulcers or any lesion with suspicion or features of malignant changes.

The diagnosis of SCC was made on the basis of history and clinical examination and confirmed by histopathological results.

Name, age, gender, onset of the burn, site of burn scar, site and nature of the ulcer, and the interval between primary burn injury and occurrence of SCC were recorded. For each patient: a full clinical examination was achieved in addition to complete systemic examination.

Oral consent was taken from each patient before starting the study. Close-up photographs were taken for each patient.

\section{Statistical Analysis}

Statistical Package for the Social Sciences version 23 was used for data input and analysis. Data were statistically described in terms of mean, frequencies (no. of cases), male to female ratio and percentage (\%).

\section{Results}

A total of 172 patients with burn scar, their ages, ranged from 1-50 years with a mean 25 years, 122 (71\%) males and 50 (29\%) females with male to female ratio was 2.44:1. All had history of burns and the age of scar was ranged from 0.5-5 years. Twelve (6.97\%) cases of SCC were seen among all patients with burn scars, their ages ranged from 25-50 years with a mean of 37.4 years and were 10 (83.33\%) males and two (16.66\%) females i.e. ratio of 5:1. The sites of these cancers were as follow: 6 (50\%) cases on lower limbs including the buttock, 5 (41.66\%) cases upper limbs and one (8.33\%) case on scalp. The associated triggering risk factors were male sex, deep burn scar with contracture, long duration, at the sites of flexures like elbows and knees. In addition to sites subjected to repeated trauma, ulcerations and infection.
Two clinical kinds of post-burn SCC were encountered:

(i) The flat, ulcerative variety with raised margins was seen in 9 (75\%) cases (Figures 1, 2, 3).

(ii) The nodular, fungating lesion was seen in $3(25 \%)$ cases.

The mean of the interval between primary burn injury and occurrence of SCC was 3.5 years. The results of histopathological studies showed well-differentiated SCC (Figure 1B).

No metastasis to the regional lymph nodes or other parts of the body was recorded during clinical examination.

\section{Discussion}

The mutagenic behavior with regular mitosis in regeneration and healing that usually follows burn scars represent the ultimate key mechanism initiating malignant transformation [8]. Although the definite pathogenesis of burn scar malignancy is not well known, multiple factors enhancing malignant transformation on burn scar have been defined. It is believed that repeated ulcers and healings particularly at the sites exposed for repeated trauma especially around joints can lead to malignant changes $[10,11,12,13]$. Chronic mechanical irritation, poor lymphatic regeneration, release of local toxins after burn injury, scar characteristics i.e. thickness, nutrition state, and degree of contraction are the other factors that may contribute burn scars to develop malignancy $[11,13]$.

In multiple reports, the mean age for SCC arising in burn scars ranged from 36 years by Iregbulem [14], to 58.5 years by Arons et al. [15]. In the present work the mean age of SCC patients was 37.4 years, this finding falls within the range of previously reported studies $[14,15]$.
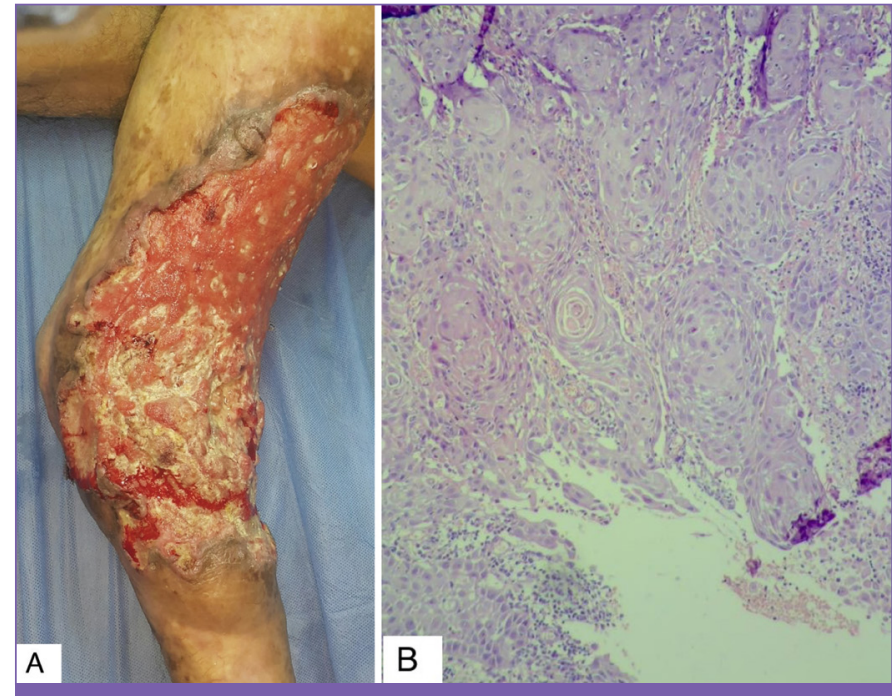

Figure 1. Thirty-five years old male with ulcerated squamous cell carcinoma arising within long standing burn scar on the left lower limb (A). Hematoxylin and eosin stained section of the same lesion showing hyperkeratosis well differentiated squamous cell carcinoma (B x10) 
It has been reported that males are mostly affected by SCC arising in burn scars $[14,16,17,18]$. In the present study, $83.33 \%$ of our cases were males and this finding is comparable with these previous studies.

The frequency of SCC among all patients with burn scars, in the current study was (6.97\%), this figure is comparable to one study [19] but slightly higher than other published works [20,21]. This finding is not surprising as sunny climatic condition during the whole year time and the early continuous sunlight exposure during outdoor activities in correlation with job time is more important for development of SCC [22].
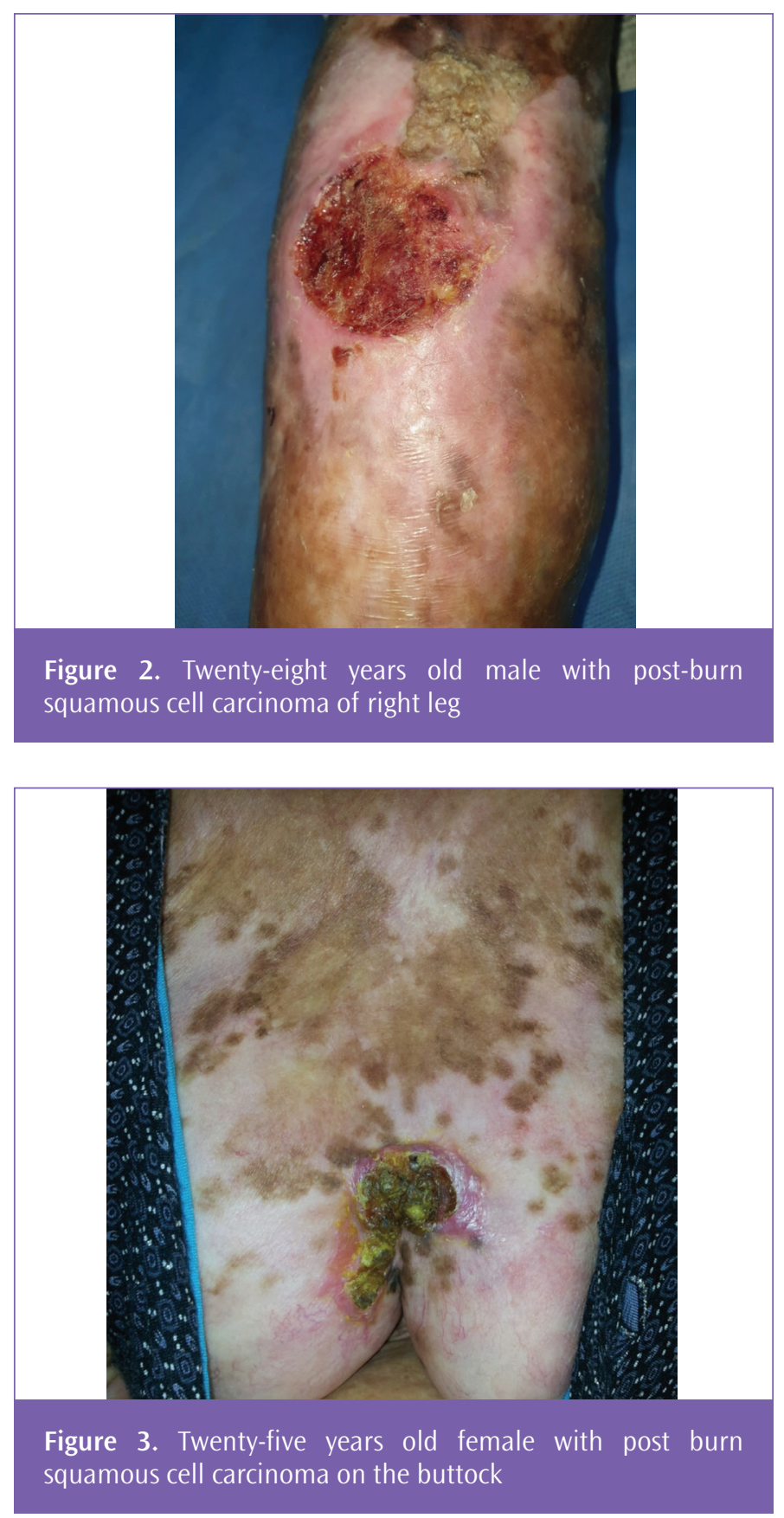

Generally, SCC is mostly seen at the head/neck, while SCC arising on burn scars is frequently localized on lower extremities, where the trauma risk is high and the blood flow is low [16] in addition, the extremities are more susceptible to deep burns than other sites of the body. In the present work, 6 (50\%) of 12 SCCs developing on burn scars were localized on lower extremities, 5 (41.66\%) cases on the upper limbs and one (8.33\%) case on the scalp. These results are in agreement with other studies $[14,17,19]$.

The mean of the latent period of SCC patients in our study was 3.5 years which is shorter than other studies $[14,17,19,18]$. A possible reason behind this disparity may be differences in ethnicity and a long-term sunlight exposure among Iraqi population which can be a causative factor for earlier development of SCC.

SCC complicating a chronic burn scar is an unusual phenomenon. About $2 \%$ of the burn scars undertake malignant change to SCC, while $0.3-0.5 \%$ to basal cell carcinoma (BCC) $[4,21]$. In the present study, all of the cases had a malignant change to SCC. No BCC or malignant melanoma was recorded.

The most important strategy for the prevention of skin cancers is the prevention of burn injuries. Prevention of infection of the burned skin and avoidance of trauma to the burn scars are other steps for the protection against the development of skin cancers. Medical management for burn scars should be started as soon as possible to minimize scar formation and reduce scar size [23].

In case of suspicion of malignant transformation in the burn scar, biopsy for histopathological studies and follow up in regular times should be done. Surgical intervention should be performed as early as indicated in case of grafting, treatment of scar contracture and excision of any scar with suspicion of malignant features.

\section{Study Limitations}

This study showing huge number of patients with well documented cases of SCC accordingly we think there is no limitation of the study.

\section{Conclusion}

The frequency of SCC among burn scars was $6.97 \%$. All patients with deep burn scar should be watched carefully for burn SCC especially scars in male with frequent infection, ulcerations, repeated trauma and contracture around the joints. Biopsy for pathological studies and follow-up to be done regularly in any ulcer of long standing burn scar to rule out any malignant transformation. Early medical therapy is strongly indicated but if this maneuver fails then excision and grafting might prevent this important complication.

\section{Ethics}

Ethics Committee Approval: The study followed the Declaration of Helsinki Principles and it was approved by the Ethics Committee of Fallujah Teaching Hospital (approval number: 887, date: 17/6/2021). 
Informed Consent: Consent form was filled out by all participants.

Peer-review: Externally and internally peer-reviewed.

\section{Authorship Contributions}

Surgical and Medical Practices: K.E.S., R.I.J., Concept: K.E.S., R.I.J., Design: K.E.S., R.I.J., Data Collection or Processing: K.E.S., R.I.J., Analysis or Interpretation: K.E.S., R.I.J., Literature Search: K.E.S., R.I.J., Writing: K.E.S., R.I.J.

Conflict of Interest: No conflict of interest was declared by the authors.

Financial Disclosure: The authors declared that this study received no financial support.

\section{References}

1. Bombaro KM, Engrav LH, Carrougher G], Wiechman SA, Faucher L, Costa BA, Heimbach DM, Rivara FP, Honari S. What is the prevalence of hypertrophic scarring following burns? Burns 2003;29:299-302.

2. Profyris C, Tziotzios C, Do Vale I. Cutaneous scarring: Pathophysiology, molecular mechanisms, and scar reduction therapeutics Part I. The molecular basis of scar formation. J Am Acad Dermatol 2012;66:1-10; quiz $11-2$.

3. Finnerty CC, Jeschke MG, Branski LK, Barret JP, Dziewulski P, Herndon DN. Hypertrophic scarring: the greatest unmet challenge after burn injury. Lancet 2016;388:1427-1436.

4. Love RL, Breidahl AF. Acute squamous cell carcinoma arising within a recent burn scar in a 14-year-old boy. Plast Reconstr Surg 2000;106:1069-1071.

5. Strom SS, Yamamura Y. Epidemiology of nonmelanoma skin cancer. Clin Plast Surg 1997;24:627-636.

6. Grossman D, Leffell DJ. Squamous cell carcinoma. In: Freedberg IM, Eisen AZ, Wolff K, Austen F, Goldsmith LA, Kats SI editors. Dermatology in General Medicine. 6th ed. New York: McGraw-Hill; 2003. p.737-747.

7. Сорсu E. Marjolin's ulcer: a preventable complication of burns? Plast Reconstr Surg 2009;124:156e-164e.

8. Kowal-Vern A, Criswell BK. Burn scar neoplasms: a literature review and statistical analysis. Burns 2005;31:403-413.
9. Fleming MD, Hunt JL, Purdue GF, Sandstad J. Marjolin's ulcer: a review and reevaluation of a difficult problem. J Burn Care Rehabil 1990;11:460-469.

10. Spring PM, Myers JN, El-Naggar AK, Langstein HN. Malignant melanoma arising within a burn scar case report and review of the literature. Ann Otol Rhinol Laryngol 2001;110:369-376.

11. Türegün M, Nișanci M, Güler M. Burn scar carcinoma with longer lag period arising in previously grafted area. Burns 1997;23:496-497.

12. Phillips TJ, Salman SM, Bhawan J, Rogers GS. Burn scar carcinoma. Diagnosis and management. Dermatol Surg 1998;24:561-565.

13. Kikuchi H, Nishida T, Kurokawa M, Setoyama M, Kisanuki A. Three cases of malignant melanoma arising on burn scars. J Dermatol 2003;30:617-624.

14. Iregbulem LM. Post-burn squamous cell cancers in Nigerians. Br J Plast Surg 1987; 40:488-493.

15. Arons MS, Lynch JB, Lewis SR, Blocker TG Jr. Scar tissue carcinoma. I. A clinical study with special reference to burn scar carcinoma. Ann Surg 1965;161:170188.

16. Lefebvre P, Rouge D, Chavoin JP, Costagliola M. Dégénérescence de cicatrices. A propos de quatorze observations [Degeneration of scars. Apropos of 14 cases]. Ann Chir Plast Esthet 1991;36:330-335.

17. Al-Zacko SM. Malignancy in chronic burn scar: a 20 year experience in MosulIraq. Burns 2013;39:1488-1491.

18. Ehsani AH, Noormohammadpour P, Nasiri N, Faraz PT, Goodarzi A Demographic and histopathologic characteristics of Marjolin's ulcers in Razi Hospital, Tehran, Iran: A 5-year survey. Iran J Dermatol 2016;19:45-49.

19. Gül U, Kiliç A. Squamous cell carcinoma developing on burn scar. Ann Plast Surg 2006;56:406-408.

20. Love RL, Breidahl AF. Acute squamous cell carcinoma arising within a recent burn scar in a 14-year-old boy. Plast Reconstr Surg 2000;106:1069-1071.

21. Phillips TJ, Salman SM, Bhawan J, Rogers GS. Burn scar carcinoma. Diagnosis and management. Dermatol Surg 1998;24:561-565.

22. Iannacone MR, Wang W, Stockwell HG, O'Rourke K, Giuliano AR, Sondak VK, Messina JL, Roetzheim RG, Cherpelis BS, Fenske NA, Rollison DE. Patterns and timing of sunlight exposure and risk of basal cell and squamous cell carcinomas of the skin--a case-control study. BMC Cancer 2012;12:417.

23. Sharquie KE, Jabbar RI. Medical therapy of burn scar before any plastic surgery by using topical corticosteroid combined with oral zinc sulfate. J Turk Acad Dermatol 2021;15:37-43. 